phenicol is probably an indirect effect although no visible lysis accompanies the inhibition.

Although the DNA metabolism of phage T 5 -infected $\boldsymbol{E}$. coli shows some unusual features, there are several similarities between the metabolism of phage T2-infected $E$. coli and phage T5-infected $E$. coli. These include the inhibition of net RNA synthesis by infection, the high rate of DNA synthesis as compared with that in the uninfected host, the activation of DNAase and the requirement for 'prior protein synthesis' before DNA synthesis. Also infection with phage T2, T4, T5, or T6 confers on $E$. coli B 3, a thyminerequiring strain, the ability to make thymine. These similarities suggest an affinity between phage $\mathrm{T} 5$ and phage $\mathrm{T} 2$ in spite of the chemical difference between the nucleic acids of the two phages, phage $T 5$ containing cytosine and phage T2 containing 5-hydroxymethyl cytosine (Wyatt \& Cohen, 1953).

\title{
REFERENCES
}

Luria, S. E. \& Steiner, D. L. (1954). J. Bact, 67, 635.

WyatT, G. R. \& Cohen, S. S. (1953). Biochem. J. 55, 774.

Folloreed by a Symposium on

\section{THE STRATEGY OF CHEMOTHERAPY}

The Relation of Strategy to Tactics: Some General Biochemical Prin-

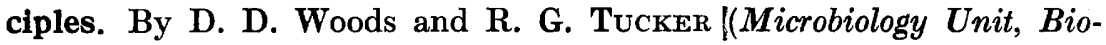
chemistry Department, University of Oxford)

The Antibiotic Approach. By. H. B. Woodruff and L. E. McDaniel (Microbiological Research Division, Merck and Co., New Jersey)

Selective Inhibition of Bacterial Cell Wall Synthesis; its Possible Applications in Chemotherapy. By J. T. PARK (Walter Reed Army Institute of Research, Washington, D.C.)

Surface Active Bactericides. By B. A. Newton (Medical Research Council Unit for Chemical Microbiology, Department of Biochemistry, University of Cambridge)

Membrane Penetration and the Therapeutic Value of Chemicals. By P. D. Mrtchell (Department of Zoology, University of Edinburgh)

Inhibitors of Energy-Supplying Reactions. By H. A. KREBS (Department of Biochemistry, University of Oxford)

Metal-binding agents in Chemotherapy: the Activation of Metals by Chelation. By A. Albert (Australian National University, Canberra)

The Designing of Anti-Metabolites. By D. W. Woolley (Rockefeller Institute for Medical Research, New York)

Lethal Synthesis. By R. Markham (Agriculture Research Council Virus Research Unit, Molteno Institute, University of Cambridge) 
Selective Inhibition of Virus Multiplication. By I. TAMM (Rockefeller Institute for Medical Research, New York)

Specific Inhibitors of Protein Synthesis. By E. F. Gale (Medical Research Council Unit for Chemical Microbiology, Department of Biochemistry, University of Cambridge)

Mechanisms of Chemotherapeutic Synergy. By B. W. LAcy (Westminster Hospital Medical School, London)

The Chemotherapy of Bacterial Infections. By R. KNox (Guy's Hospital Medical School, London)

The Chemotherapy of Fungal Diseases. By R. J. W. ByRdE (Research Station, Long Ashton, Bristol) and G. C. AInsworth (Commonwealth Mycological Institute, Kerw)

The Chemotherapy of some Protozoal Infections; Factors Affecting the Chemotherapy of Amoebiasis. By L. G. Goodwin and R. A. NEaL (Wellcome Laboratories of Tropical Medicine, London) 